\title{
18. 居住地移転による通勤行動を中心とした移動行動の变化に関する調查研究
}

\author{
東京工業大学大学院 原 科 幸 縓
}

\section{1,はじめに}

都市空間の良し悪しを測る一つのメシャーとして移動行動の容易さが考えられる。移動行動には時間的, 経済 的，肉体的なコストがかかり，てれが行動空間の選択を制約し，人の行動を規定している。これらのコストのう ち特に克服困難で基本的なるのは時間であり，移動時間の大小は都市活動のやりやすさを表わす有力な指標であ る。一日とか一週間とかのサイクルの中で配分される移動時間量は都市住民の個人属性だけでなく，都市空間の デザインに依存する。同じ行動欲求パターンを持った人間集団であれば総移動時間の差は都市空間の違いによる。 また，空間条件の違いは行動欲求に影鄉を与えるから移動距離が 2 倍になったから 2 倍の移動時間配分がなされ るとは限らない。移動距離が遠くなれば移動の発生回数を隇らすように行動するであるう。したがっててのよう な移動行動一空間の関連を明らかにしておかなければ都市空間の良し悪しを測るメジャととしての移動時間指定 を行ならてとはでをない。そてで，都市における移動行動が空間によって，特にその変化によってどのように影 響を受けるかを明らかにするてとが必要となる。そのために，今回，東京の都心部かよび郊外の地区で，最近居 住地の移転した世帯を対象とした調査を実施し，その構成員である夫，妻，子の移動行動が居住地の違いによっ てどのように異なるかその差違を明らかれする目的で分析を行なった。

\section{2 , 調 査の 概 要}

調查対象とした地区は東京都心部は目黑駅周辺のマンションと厷尾駅前都営住宅, 郊外部は多摩ニュータゥン の永山団地。諏訪団地である (眓一 1 )。調查時点は郊外部が 1973 年 7 月 9 日〜 17日,都心部が 7 月 23 日〜 26 日，調查対象回収世帯数は郊外部で 261 , 都心部が 172 の計 433 世帯である。個人単位では郊外部で有職者, 主婦，学生がそれぞれ $256 ， 256 ， 48$ ，都心部で 167 ， 図-1 調查対象地区

$171 ， 85$, の合計 983 票が回収された。このうち学生の 票数が少ないのは現在未就学および以前の居住地におい ては未就学であった児童は調查対象からはずしたてとと， 回答者の潘とんどが主婦であったため主人以外の家族の 行動について站不明な点が多く除外されたるのるかなり あるためである。

調查項目は家族全体については，前住地，現在の居住 地入の入居年月，家族構成，家族全体での休日の外出行 動の現在と以前の比較，休日の外出行動が変化した場合 その理由，家族の中で特に生活行動飞変化のあった人は 誰か等である。主婦については年令，続柄，日常的買物， 非日常的買物の現在と以前の比較，現在と以前の起床晆 刻，就寝時刻等である。有職者および学生につんては性 別, 年令, 職業 (学生は学校) を, そして通勤通学先, 起㦿時刻，就寝時刻，片道の通勤通学時間，通勤通学経 路, 通勤通学時の疲労, 朝の自宅でのあわただしさ, 夜

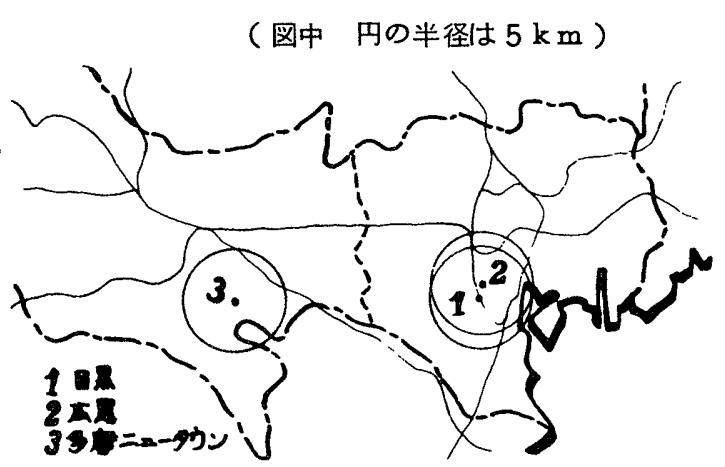

表- 1 回収サンプル数

\begin{tabular}{|c|c|c|c|c|c|c|}
\hline & 世帯数 & 有職者 & 主婦 & 学生 & サンプル計 \\
\hline \multirow{2}{*}{ 都心部 } & 目 黒 & 80 & 81 & 79 & 48 & 208 \\
\hline & 広 尾 & 92 & 86 & 92 & 37 & 215 \\
\hline \multirow[b]{2}{*}{ 郊外部 } & 永山団地 & 145 & 148 & 144 & 32 & 324 \\
\hline & 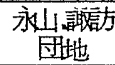 & 116 & 108 & 112 & 16 & 236 \\
\hline \multicolumn{2}{|c|}{$\begin{array}{l}\text { 計 } \\
\text { 㘯 }\end{array}$} & 433 & 423 & 427 & 133 & 983 \\
\hline
\end{tabular}


の家族との接触，平日の帰宅途中の寄道行動, 㷌宅後の再外出行動, 休日の単独あるいは家族以外之の外出行動 等について現在と以前の比較を行なった。さらに主婦, 有職者, 学生それぞれの生活行動の変化やその理由につ レてもインタビニーを加えてある。買物行動, 寄道行動, 再外出行動, 休日の外出行動はいずれるその頻度, 片 道の移道時間, 行先, 行動内容を質問した。

\section{3, 居住地移転による世帯構成員の主要な移動行動の变化}

世带を構成するメンバーは核家族では夫，妻，子代分けられ，今回の調査対象ではそれぞれ有職者，主婦，学 生の分類と対応している。郊外部は都心部よりる世帯主の若い世帯が多く調查対象となる子供のない世帯が多加 った。世帯を構成するメンバー個々の移動行動の主要なるのは有職者, 学生は通勤通学行動, 主婦は日常的買物 行動である。とてではこれらの移動行動が居住地の变化によってどら変わったかその時間配分について見る。

\section{[有職者の通勤時間 ]}

今回の調查対象の有職者はほとんどが世帯主であり，居住地選定の際その通勤時間が大をな要素となると考え られる。そてでどてから転居して来たかを見ると都心部では現住地 の近辺加らの転居が多く半径 $5 \mathrm{Km}$ 以内加らの転居世帯が目黒, 厷尾 ともに40\%を占める。てれ対し多摩ニュータゥンでは遠隔地から の移転が目立ち半径 $5 \mathrm{Km}$ 以内からは18\%にすざず，乙れ以外の都下 から30\%，23区内からは33\%となっている。とのととから都心部で の職住近接郊外部ての職住遠隔が予想される。（図一2,3）を見る とての関係は明らかに現われており有職者の通勤時間は都心部では 減少した人が多く，郊外部では增加した人の方が多くなっている。 しかし一様に增减の傾向が見られるのではなく通勤が不便だといわ れている多摩ニュータゥンでる通勤時間の減少した人がかなりあり， 都下に職場をるつ人が職住接近を行なっているととる示している。

\section{[子(学生)の通学時間]}

有職者に対し学生はその䘑とんどが世帯の中では子でり居住地 選択の際, 世帯主の犠牲になりがちな存在である。学生の中です中 学生以下と高校生以上て壮居住地移転後の通学先の変更の可能性と らら点で大きな差があるため通学時間の変化にもその差が大きく現 われる(表一2)。以前の居住地では小学生であったのが現在は中 学生になっている場合, その間の進学による通学時間の増加の可能 性が考えられる。したがっててのようなサンプルを除いて現在と以 前の通学時間を比較してみると中学生以下では都心部で平均 5 分, 郊外部で平均10分弱の通学時間の増加が見られ, 高校生以上で都 心部では 2 分, 郊外部ては40分近くの増加となっている。都心部で は有職者全体では通勤時間の減少傾向が見られるのに対し，学生は 逆の方向飞変化しており，郊外部ではいずれるが増加している。て れは核家族を構成している世帯員についてのととであり学生全般に ついてではないととに注意する必要がある。

\section{[主婦の日常的實物移動行動]}
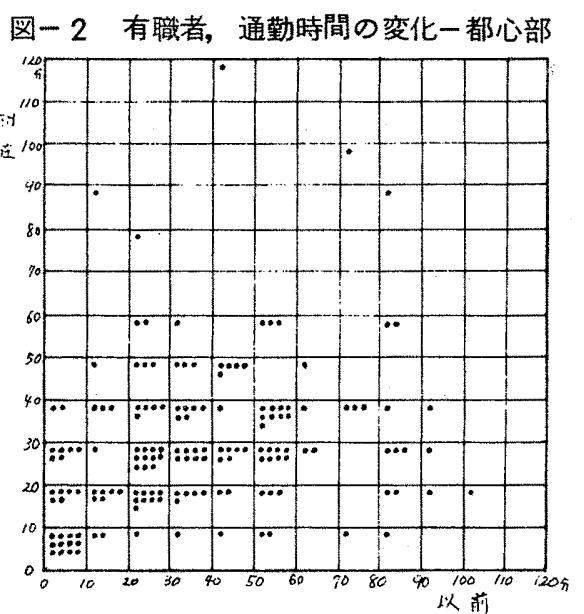

図-3 有職者, 通勤時間の变化一郊外部

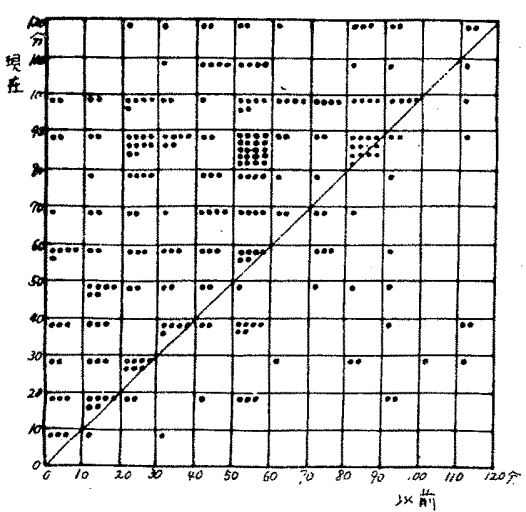

表一 2 通学時間の增減

\begin{tabular}{|c|c|c|c|c|c|c|}
\hline & & 隇 & 不簽 & 增 & 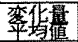 & サンブル数 \\
\hline \multirow{2}{*}{ 中学以下 } & 都心部 & $33 \not$ & 9 & $58 \not$ & +4.3 分 & 43 \\
\hline & 好外部 & 29 & 5 & 67 & +9.1 & 21 \\
\hline \multirow{2}{*}{ 高校以上 } & 都心暗 & 40 & 20 & 40 & +2.0 & 10 \\
\hline & 奴外部 & 0 & 14 & 86 & +37.9 & 7 \\
\hline
\end{tabular}

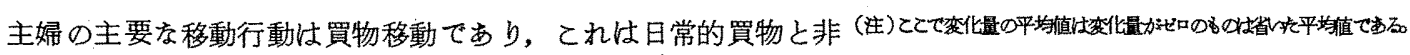


日常的買物とがある。住居の近隣商店街での日常的買物が主挶にと っての主要な移動行動と考えられ，町へ出るといった形の非日常的 買物は移動距離が長らがその頻度は少なくこの調査でも月単位や季 節単位の行動となっている。そてで常的買物のための移動時間配 分を 6 日間て換算した片道の移動時間配分として示したのか（図一 4,5 )である。乙の図ではX軸に以前の，Y軸に涀在の移動時間量 を示してあるが，てれによると都心部と郊外部とでは移動時間配分 パターンに若干の差が見られる。都心部では以前と現在の時間量の 変化は増减同じょうな分布であるのに対し，郊外部では以前よりる 現在の移動時間量配分の增加している人が多くなっており，てれは 郊外部（多摩ニニーダウン）に転居した世帯は, 日常的買物の便が 全般的には悪くなったためと考えられる。(図一 4,5)の下のクラ フは以前と現在の移動時間配分からそれぞれ 6 日間換算で最大限何 分まて移動時間配分を行をっているかの累積頻度分布である。都心 部についてみると大体60分までで全体の90\%以上が含まれており， 郊外部ではての時間量までに全体の60\%，90分以内で全体の90\%が 含まれている。このととから日常的買物行動は移動時間と頻度との 間に一定の調整関係が働いているととが推测され，移動時間が片道 10分以内では毎日，20分では 2 日に 1 度，30分では 3 日に 1 度とい うような調節がなされると考えられる。移動時間長の増減と行動頻 度の増減の関連を調べると片道移動時間長の㚆化に対し行動頻度を 変化させたるのは都心部では35\%，郊外部では42\%である。そのう ち移動時間長の増加 (減少) 飞対し行動頻度を減少（増加）させた あのは都心部では70\%，郊外部では87\%となっており，ての差は郊 外部の方が買物移動の便が悪くなった人が多いためと思われる。

\section{4, 通勤時間の生活行動人の影響}

前節では世带構成員のそれぞれについてその主要な移動時間が居 住地の変化についてどら変わるかを見た。このらち有職者の通勤行 動は職場と住居の位置関係に依存するるのであり，都市空間形態と 移動行動の関係を考える場合最る基本的をるのといえる。そてで以 下二節は特に通勤行動についての分析を行なった。

通勤時間長の生活行動への影警は種々考えられるが，通勤時の影響として主要なるのは通勤疲労である。また 通勤行動が他の生活行動に及ほす影響を生活時間の側面でとらえると行動の場としての自宅空間にいる時間長へ の影響もまた大りと考えられる。こてではこの二つと通勤時間との関連について分析した。

\section{[通勤時の疲労]}

一般に通勤時間は矢かければ短かいほど良らと考えられるが, それは通勤による肉体的, 時間的, 経済的コス トが増大するからである。通勤時間の許容限界值はこれらのコスト, 中です肉体的コストとしての疲労との関連 でらえられての面での研究も多い。今回の調査でる疲労度に関する質問をしており, 通勤時間長と疲労度との 関連を見ると通勤時間が50分以下で疲学なしといら人が50\%を越え，50分を越すと疲労感を訴える人の方が多 
くなる。まを都心と郊外では同じ通勤時間でも郊外の方が疲労感を訴える人の割合が多くなっている。

通勤時の疲労は通勤時間長だけでなく交通手段の種類や混雑の度合によってもをく左右される。一般に自動 車利用者上りる鉄道利用者の方が特にその混雑による疲労が大きいと答えている。自動車利用者の中には通勤時 間自体牥以前よりるずっと長くなったのにすかかわらず道路が以前よりすすいているので楽になったと答えてい る人がある。都心部居住者で通勤方向が郊外に向ら鉄道利用者の中には車内がすいているので楽だと答えた人る らる。また移動時間は交通機関に乗っている時間と駅での乗り換え，待ち合わせの時間に分けられ，後者の時間 による苦痛が大きいというととが，同一の通勤時間ながら乗り換え回数が一つ増加したたるに大変だと回答して レる人がいるととからる知るととがでをる。

\section{[通勤時間と在宅時間]}

通勤時間と生活時間の関連を生活行動の主要な場であ る自宅にいる時間（在宅時間）との関連として分析した。 とてでいら在宅時間とは在宅して起をている時間をいい 睡眠中の時間は含なない。通勤者の場合との時間は一般 には朝の出勤前の時間と, 夜の䚻宅後の時間の二つに分 けられ，それぞれについて通勤時間との関連を見た。

朝の在宅時間は通勤時間が長ければ切りつめ, 通勤時 間が短かければ在宅時間は長いと予想されるが，実際は （図一6）に見るように怖とんど関係はない上うである。 通勤時間の変化に対してはどらであるらか。通勤時間が 増加すれば在宅時間を以前と同じだけ確保するためには 起休時間をくり上げなければならないが，それ反る限度 があり在宅時間自体の切りつめる行なわれるであるう。 調查結果から見ると在宅時間を以前と同しだけ確保する 人は都心部て7 $70 \%$ ，郊外部で $33 \%$ となっており，乙の差 は郊外部では通勤時間の增加した人が多いので在宅時間 を切りつめる人が多いためと考えられる。通勤時間の変 化住対し在宅時間を変化させる人たちは，大体二つのク ループに分けられる。一つは通勤時間の增减に対して在 宅時間を増減させるクループで，他壮通勤時間の増加に 対し在宅時間る增加させるグループである。前者は69\% を占め通勤時間の堌减に対し在宅時間を切りつめる行動 をとってかり，その調節量の上限値が通勤時間の增减と ほ㴗一致している。したがってある程度起休時刻を動か し足りない分を在宅時間で調節しているといえる。また 通勤時間の増加に対し在宅時間も增加させる人は2 $25 \%$ るが, 通勤時間の減少に対し在宅時間も減少させる人は $6 \%$ ぼとんどない。

夜の在宅時間についてる同椂に見てみると通勤時間長 と在宅時間との関連壮やはりあまり明らかではないし

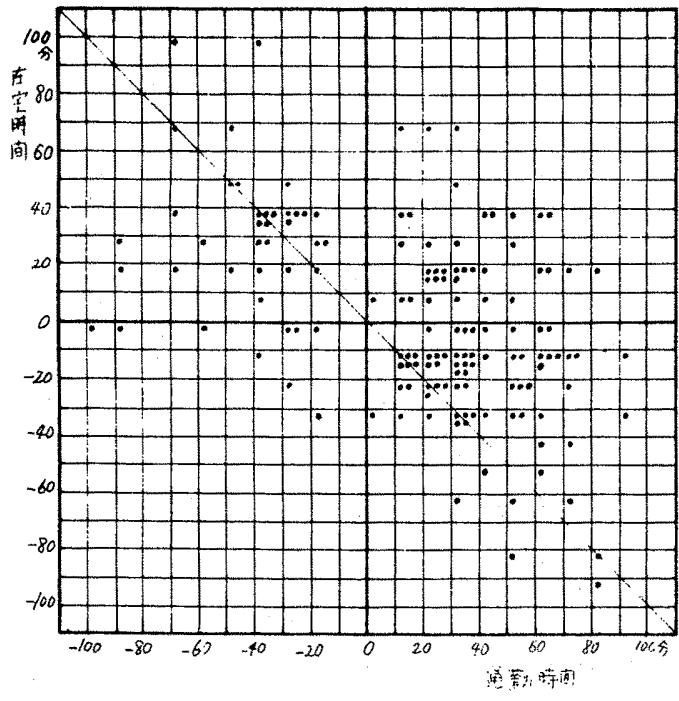

図一 7 夜の在宅時間の変化と通勤時間の变化

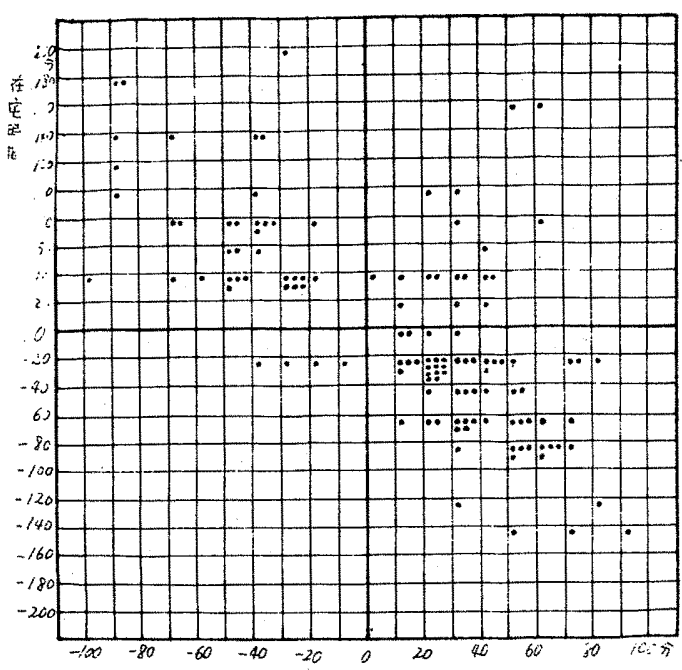
かし在宅時間の上限值については直線的な関連が見られ 
る(図一 7 )。通勤時間の変化に対する在宅時間量の変化る朝の場合と同じようなパターンが見られる。通勤時 間の変化に対し在宅時間を以前之同じだけ確保する人は都心部で $67 \%$ ，郊外部で37\%あり朝の場合とに缥同じ值 である。通勤時間の増加（減少）飞対して在宅時間を減少（増加）させるグループは夜では81\%を占め朝よりか なり多い。これは通勤時間の増加とともに在宅時間る増加させるグルーブが15\%と減ったためであり，前二つの クループに分けられるといえる。夜の在宅時間よりる朝の在宅時間の方が通勤時間の影響を強く受けそらだが， この結果からは夜の在宅時間の方が通勤時間変化の影響を受ける人が多いといえる。てれは朝の時間がるとると ぎりびり切りつめられた時間であるのに対し夜はかるり弾力性のある時間であるととによると考兄られる。この ことは通勤時間の增堿に対する夜の在宅時間変化の上限値が朝の $2-3$ 倍になっているととにも現われている。

\section{5，通勤時間の他の移動行動人の影響}

通勤時間は他の移動行動にはどのようを影響を与えているかを見るために，業務以外の日常の移動行動を平日 は帰宅途中の寄道行動，滞宅後の再外出行動，休日は通勤者単独ないしは家族以外の人との外出行動について通 勤時間との関連を分析した。

\section{[平日の寄道行動]}

通勤時間長と寄道行動発生回数の関連を見ると，奇道行動を行なっている人の割合は（表一 3 ) に見るよらに 通勤時間との関連はあまり明確ではない。寄道行動を行なら人についてその週当りの平均寄道回数と通勤時間の 関連を見てもあまり明確な関連は見られない。しかし，よく見ると通勤時間が 1 時間をでとそれ以上とで梯子 が異なり通勤時間が 1 時間亲では行為者比率, 平均頻度とるに正の相関が見られる。てれは通勤時間が 1 時間ま での間では通勤時間の減少は行動余裕時間の 增加という効果よりす通勤距離の減少による 寄道先の選択性低下の効果をるたらし直行帰 宅型を増加させているすのと考えられる。通 勤時間が 1 時間を越えると寄道先の選択性高 上とともに通勤疲労やその他の影響が加わり 通勤時間との間には明確な関連が現われなく なる。インタビュー調査の回答では通勤時間 が長らので疲れるため途中で一休みする意味 で寄道行動を行ならといらものるあった。

寄道行動をする人のらち通勤時間の変化に 対し寄道行動の頻度を変えない人は $55 \%$, 増 加させる人は $14 \%$ ，減少させる人は $30 \%$ で る。頻度を增加させる人の割合は通勤時間の 増减と汪とんぞ無関係で一定で, 都心部と郊 外部の差るなく, 通勤時間の変化は寄道行動 頻度を増加させる主要なファクターではない と考えられる。しかし，頻度を減少させる人 の割合忙通勤時間の増減と一定の関係があり， 通勤時間の絶対値の増加は寄道行動の頻度を 減少させている(表一4)。

\section{表 -3 通勤時間と平日寄道行動の関連}

\begin{tabular}{|c|c|c|c|c|c|c|c|}
\hline 通勏間（分） & $0 \sim 19$ & $20 \sim 39$ & $40 \sim 59$ & $60 \sim 79$ & $80 \sim 99$ & $100 \sim 119$ & $120 \sim 139$ \\
\hline 行為者比率 (抏) & 44 & 50 & 60 & 43 & 60 & 55 & 69 \\
\hline 行為者平均頻度 (回／遇） & 2.1 & 2.4 & 2.7 & 1.7 & 23 & 1.9 & 2.1 \\
\hline サンブル数 & 36 & 110 & 60 & 54 & 75 & 43 & 14 \\
\hline
\end{tabular}

表一 4 通勤時間の変化と平日寄道行動頻度の増減 （寄道行動のある人について）

\begin{tabular}{|c|c|c|c|c|c|c|c|}
\hline 通珤時間の変化（分） & $\sim-60$ & $-59 \sim-30$ & $-29 \sim-1$ & 0 & $1 \sim 29$ & $30 \sim 59$ & $60 \sim$ \\
\hline 頻度增加（片） & 13 & 19 & 14 & 19 & 17 & 10 & 13 \\
\hline 皟度城少（加） & 47 & 19 & 17 & 14 & 29 & 31 & 54 \\
\hline
\end{tabular}

\section{表一 5 通勤時間と平日再外出行動の関連}

\begin{tabular}{|c|c|c|c|c|c|c|c|}
\hline 通動時間 (A) & $0 \sim 19$ & $20 \sim 39$ & $40 \sim 59$ & $60 \sim 79$ & $80 \sim 99$ & $100 \sim 119$ & $120 \sim 139$ \\
\hline 行為者比事 (哜) & 29 & 25 & 15 & 22 & 7 & 7 & 7 \\
\hline 行為者平均類度（回／週） & 2.2 & 1.6 & 1.6 & 1.4 & 1.7 & 15 & 0.5 \\
\hline サンフル数 & 38 & 109 & 65 & 60 & 72 & 43 & 14 \\
\hline
\end{tabular}

表一 6 通勤時間の変化と平日再外出行動頻度の増減

\begin{tabular}{|c|c|c|c|c|c|c|c|}
\hline & \multirow{2}{*}{$\begin{array}{l}\text { 外出 } \\
\text { क }\end{array}$} & \multicolumn{4}{|c|}{ 外出有 } & \multirow{2}{*}{$\begin{array}{l}\text { 現住地での } \\
\text { 外出有 } b\end{array}$} & \multirow{2}{*}{$\begin{array}{c}\text { サンブル } \\
\text { 数 }\end{array}$} \\
\hline & & ât $\%$ & 頻度增 & 頻度不変化 & 頻废減 & & \\
\hline $\begin{array}{c}\text { 都 心 部 } \\
\text { (通勒時問变化 } \text { 平均値) }\end{array}$ & 73 & 27 & $\begin{array}{c}13 \\
(-26 \text { 分 })\end{array}$ & $\begin{array}{c}10 \\
(+6 \text { 分 })\end{array}$ & $\begin{array}{c}4 \\
(+32 \text { 分 })\end{array}$ & 26 & 167 \\
\hline $\begin{array}{c}\text { 矨 外 部 } \\
\text { （通勳時間変化の平均值） }\end{array}$ & 80 & 20 & $\begin{array}{c}4 \\
(+6 \text { 分 })\end{array}$ & $\begin{array}{c}5 \\
(+12 \text { 分 })\end{array}$ & $\begin{array}{c}11 \\
(+24 \lambda)\end{array}$ & 12 & 242 \\
\hline
\end{tabular}




\section{[平日の再外出行動]}

帰宅後の再外出行動を行なら人の比率は寄道行動を行なら人の比率よりすずっと少なくその $\frac{1}{2} 2$ から $\frac{1}{4}$ である。 都心部之郊外部といら地域性の差から都心部では26\%, 郊外部では12\%の人が再外出行動を行なっている。てれ は再外出行動の目的は食事や娱楽, 買物, 散歩が多く, これらの行動を可能にする施設が今回調査では郊外部よ りる既存市街地，と近接している都心部の目黒，広尾の方が多いためと考えられる。

通勤時間との関連は寄道行動よりも強いよらであり, 再外出行動を行なら人の比率は通勤時間の增加とともに 减少の傾向を示し通勤時間が80分以上では再外出行動を行なう人はわずかである（表一 5 ）。てれは通勤時間の 増加によって帰宅後行動時間量の減少，通勤疲労の增加，㷌宅時刻自体の遅れなどが生じるためと考えられる。 再外出行動を行なら人の一週間当りの平均再外出行動数も通勤時間量に対し再外出者比率と同じよら傾向を示 している。

通勤時間の変化と再外出率の関係を見ると, 再外出を行なわない人の通勤時間の変化量は広い範囲にわたって おり通勤時間の変化が直接再外出行動の発生を促すとは考えられない。個人の性向とか, 地域の空間条件, 家族 の特性など他の要因が再外出行動の発生を支配するすのであるら。しかし再外出行動を行なう傾向のある人に限 つて見ると通勤時間の増减との関連は明膫である。（表一6）に示すよらに，都心部で再外出行動を行なら人の うちその頻度が変化していない人は通勤時間の変化す小さく平均 6 分ほど増加にすどないとてろが頻度の増 加した人の通勤時間は平均26分の減少, 頻度の減少した人は逆に平均32分の通勤時間増加が見られる。このとと から再外出行動を行なら傾向のある人に関しては通勤時間の增减の影響を受けるるのといえる。

\section{[休日の外出行動]}

平日の通勤時間の長さは休日の外出行動の発生に影遙を与えるであろらか。定量的にとらえてみると都心部で は外出行動の上限值と若干の関連が見られるが，郊外部についてはほとんと関連は読みとれない。インタビニー の回答の中には平日の通勤時間が長くなったので休日の外出が減ったといらすのがかなりあったが，子供の成長 による影響を強調する人る多くこちらの影響の方が強く現われるるのと考えられる。

\section{6,むすび}

今回の調査は小標本によるるので統計的結論を提示するととはでをなが,インタビューによる考察を加えて おり大標本調査です今回の結果とそれほと異なる結果に達するとは思われない。居住地移転による移動行動の 変化は世帯を構成するメンバーの属性によって異なり，通勤通学先を簡単に変えることのでさない有職者や高校 以上の学生はこの影響を直接に受けている。中学生以下の子供や主婦は移転先に新たな通学先, 買物先を求める のが一般で，主婦の場合は日常的買物移動時間の増减に対し行動頻度を減増して一定サイクル内での移動時間総 量がある幅の中に收まるように調節しているととがわかった。てれと同様の調節行動は通勤者の寄道行動，再外 出行動にる見られた。人間行動の生起には数多くの要因が複雑にからみあっており，特定の要因だけで説明する ことはでをないが，ある行動を行ならカテゴリーの人に関しては移動時間の大小はその行動動機に明らかに影響 している。ての影響は有職者の再外出行動に関する分析で見をよらにむしろネガティブなるのとして動いている。 したがって移動時間が必要以上に多くかかる都市空間は行動のポテンシャルといら点て望ましい都市空間とは言 えない。ての必要以上とはどれだけを指すか，その基準を明らかにしてゅくてとが今後の課題である。

最後に, 本研究を進めるに当り常に御助言御指導を頂いた東京工業大学熊田形宣助教授に感謝の意を表する次 第です。また作業に当り援助御協力を頂いた同大学社会工学科林研究空, 熊田研究室の皆さんにお礼申しHナ゙ます。

\section{[参考文献]}

牛見 章, 「居住地限定階層怆関する一連の研究, その $1 」$ 日本建築学会論文報告集, 昭和48年 1 月号 高山英華編，「都市生活者の生活圈行動」地域社会研究所, 1968 原科幸彦, 松木伸男, 「都市の生活時間構成」日本都市計画学会学術講演会論文集, 第 7 号, 1972 